\title{
2019 年版 透析排水基準
}

\author{
日本透析医学会 $/$ 日本透析医会 $/$ 日本臨床工学技士会 \\ 峰島 三千男 ${ }^{1}$ 友 雅 司 $^{2,3}$ 中元 秀 友 ${ }^{4}$ 宍戸 寛 治 2,5 \\ 秋澤 忠男 ${ }^{6}$ 内野 順 司 ${ }^{2,7}$ 本 間 崇 ${ }^{8}$ \\ ${ }^{1}$ 日本透析医学会学術委員会透析排液管理ワーキンググループ委員長 \\ ${ }^{2}$ 同委員 ${ }^{3}$ 同学術委員会委員長 ${ }^{4}$ 同理事長 \\ ${ }^{5}$ 日本透析医会 ${ }^{6}$ 同会長 \\ ${ }^{7}$ 日本臨床工学技士会 ${ }^{8}$ 同理事長
}

\section{はじめに}

2017 年末，都内透析施設からの下水道法基準を著しく逸脱した排水によって下水道管損傷事故 ${ }^{1)}$ が発生した？ の後, 東京都下水道局長より日本透析医学会, 日本透析医会および日本臨床工学技士会あてに「透析装置の洗浄排 水に関する調査の実施について」(平成 30 年 9 月 25 日 30 下施排設第 116 号の 2) の依頼があった. 2018 年秋に害 施した上記 3 団体合同の調查の結果 ${ }^{22}$, 都内透析施設 323 施設から回答があり, 透析排水に対して適正な処理がさ れていない施設が $200 （ 63.5 \%$ ）にも及び，しかもその未処理施設のうち 155 （78.7\%）施設は透析排水に基準があ ることを知りながら何ら対策を講じていないことも明らかとなった.

公共下水道への排水に関しては，下水道法ならびに各自治体条例により基準が適用されており，特に基準を逸脱 した酸性排水が下水道に流されると，コンクリート製の下水道管が損傷し，最悪の場合道路陌没等を引き起こす恐 れがある。

2019 年 1 月 25 日に上記 3 団体理事長/会長名で会員向けに「透析施設の排水による下水道管損傷事例発生とその 対策について」という会告が出され, 同時に国土交通省, 厚生労働省, 日本医師会, 東京都下水道局からも注意喚 起が出された．早速 3 団体では「透析排水管理ワーキンググループ」を設立し, 関係団体（日本医療機器テクノロ ジー協会 Medical Technology Association of Japan：MTJAPAN，中和処理メーカーなど）の協力のもと具体的な 対策の立案に向けて検討してきた，その結果，同年 4 月 1 日には「透析関連排水に関する勧告」を 3 団体より発出 するとともに排水管理の重要性について啓発活動を展開してきた。

以上の経緯を踏まえ，このたび透析排水に関する関係法規を順守し適正な排水管理を実施することを目的に 「2019 年版透析排水基準」を策定したので報告する.

\section{I . 透析排水基準}

\section{1. 排水基準}

透析医療機関から公共下水道へ排水する場合，下水道法施行令ならびに各自治体下水道条例で定める下水排除基 準を順守しなければならない。 とりわけ, 以下の 2 項目については特段の注意が必要であり, 中和処理装置（シス テム) 等の除害施設の設置が必要である.

1）水素イオン濃度（pH） 5 を超え 9 未満

2) 温度 $45^{\circ} \mathrm{C}$ 未満

峰島 三千男 東京女子医科大学臨床工学科％ $\quad$ 162-8666 東京都新宿区河田町 8-1

Michio Mineshima Tel:03-3353-8112 Fax:03-5269-7760 E-mail:mmine@twmu.ac.jp 


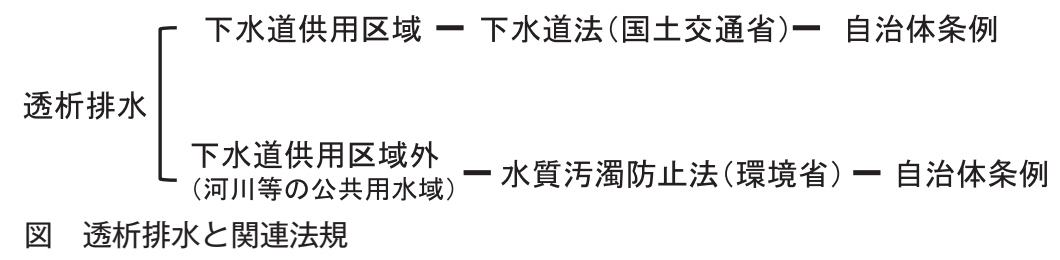

解説

透析医療機関を含む事業場からの公共下水道への排水には下水道法施行令ならびに各自治体下水道条例で定める 下水排除基準 ${ }^{3)}$ が適用される. 本基準は, 元来公共用水域の水質保全ならびに下水道管等の下水道施設の保護を目 的として制定されたもので, 下水を適正に処理して安全に川や海に排水するための基準である.

一方，透析装置や配管を維持するために各種消毒剤や洗浄剤が使用される，近年オンライン HDF をはじめとす る滤過型血液浄化法の進展に伴い, 配管スケールの除去を目的として $\mathrm{pH}$ の低い酸性洗浄剤が広く使用されている が，透析排水に適正な処理が行われなければ，コンクリート製の下水道管を腐食損傷し， 円滑な下水道事業へ支障 をきたす恐れがある。

以上の理由から, 本基準では透析医療機関における中和処理装置（システム）の設置を原則とした.

都心部では透析医療機関のスペースや設備（ビルディング）の関係で, 市販の中和処理装置（システム）の導入 が困難なケースが想定される。 これに対し, 医療機関内で簡易的に中和処理する方法がいくつか提案されている.

この簡易的方法については今後も新規に考案・開発される見込みであるが, 下水排除基準を满たすものであれば広 く容認されるべきものと考える，ただし，後述する届出ならびに適正な管理が前提となる.

一方, 公共下水道が普及していない地域もある (図)。このような下水道供用区域外の場合, 排出者は適正な排水 処理（補足参照）を行った後に河川等の公共用水域へ放流する必要がある。この場合, 放流水には水質污濁防止法 （環境省）ならびに各自治体が条例で定める排水基準が適用される4).

なお，排水の $\mathrm{pH}$ ならびに温度の基準值に関して，自治体によってその数值が異なる場合があるので確認が必要 である.

\section{2. 除害施設の届出}

透析医療機関内に, 中和処理装置（システム）等の除害施設の新規設置や更新を行う場合，各自治体所管の下水 道事務所まで届出が必要である。

\section{解説}

透析医療機関等の事業場からの排水に対していくつかの規制がある.

新たに除害施設を設置する場合もしくは除害施設を更新する場合, 各自治体所管の下水道事務所までその旨届け 出る必要がある。この届出には, 透析施設の概要, 除害施設の構造や使用方法, 処理対象項目の設置前後の測定值 等の記載が含まれる.

除害施設の届出方法やその内容については, 自治体によって異なる場合があるので確認が必要である.

\section{II．適正な消毒剂・洗浄骫の使用}

透析排水基準を満たすためには適正な消毒剤・洗浄剤の使用が望まれる.

\section{解説}

中和処理装置（システム）には，処理可能な流入排水 $\mathrm{pH}$ の範囲が取扱説明書等に明記されている．これを逸脱 する消毒剤・洗浄剤の使用は適正な排水管理を困難とする恐れがある. 具体的な消毒剂・洗浄剂の選択においては, 透析装置メーカー, 中和処理システムメーカー, 消毒剤・洗浄剤メーカーと十分相談の上, 実際に排水 $\mathrm{pH}$ を測定 するなどの確認作業が必要である. 最終的には, 透析機器安全管理委員会でその安全性, 医学的有効性等を十分議 論し，委員会の責任において決定するものとする. 


\section{III. 適正な排水管理}

排水が基準を満たしているか，日常的な排水モニタリング（pH 測定等）を通じて適正に管理する必要がある.

\section{解説}

中和処理装置（システム）の導入，適正な消毒剤・洗浄剤の使用だけでは十分な管理とはいえない. 以下に適正 な排水管理について述べる。

\section{1) 水素イオン濃度 $(\mathrm{pH}) 5$ を超え 9 未満}

$\mathrm{pH}$ の測定回数は 1 月に 1 回，望ましくは 1 週に 1 回以上 $\mathrm{pH}$ が最小と予想されるタイミングで測定する.ただ

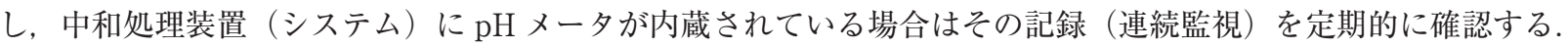

医療機関内で簡易的に中和処理する方法を用いる場合においても, 施設の透析排水流路を確認し, 最終地点（透 析室または施設外に排出される直前）の排水の $\mathrm{pH}$ を測定し確認・記録する.

2) 温度 $45^{\circ} \mathrm{C}$ 未満

透析システムを熱水消毒（主に $85^{\circ} \mathrm{C}$ 以上）する場合, 排水時の温度を監視する安全機能（希釈または自然冷却に よるもの）が正常に作動し，基準温度未満であることを $\mathrm{pH}$ の測定に準じて定期的に確認・記録する.

これらの確認方法, 頻度, 記録方法等は透析機器安全管理委員会の承認を得た後に運用する必要がある。透析機 器安全管理委員会が設置されていない施設においては医療機器安全管理責任者の所轄する委員会がこれを代行する. 排水の $\mathrm{pH}$ ならびに温度の測定に関して, 自治体によってその内容が異なる場合があるので確認が必要である.

(補足)

\section{下水道供用区域外における透析排水の適正な処理}

下水道が未普及の下水道供用区域外ではし尿，雑排水は浄化槽によって処理されるが，浄化槽にはし尿，雑排水 以外の工場排水や特殊な排水を流入させてはならないことが, 浄化槽法施行規則第 1 条四で定められている. ここ で雑排水とは台所，風呂，洗濯等の排水であり，透析排水は特殊な排水ということになる．従ってこの区域の透析 施設は浄化槽以外の排水処理設備で透析排水を処理することを検討しなければならない. この場合, 水質污濁防止 法に基づく各自治体が条例で定める排水基準が適用され，pH だけでなく，BOD：biochemical oxygen demand（生 物化学的酸素要求量）なども対象となる. 従って中和処理装置（システム）の他にBODについては活性污泥法な どの生物学的排水処理プロセスからなる排水処理設備が必要となる.

\section{文献}

1）東京都下水道局. http://www.gesui.metro.tokyo.jp/topics/touseki/index.html

2）内野順司, 峰島三千男, 友雅司, 宍戸寛治, 本間崇, 中元秀友, 秋澤忠男. 委員会報告「透析システムからの排水に関 する調査報告」. 透析会誌 2019；52：387-95.

3）東京都下水道局.一快適な水環境をめざして一 事業場排水 水質規制のあらまし. 東京都下水道局パンフレット, 2019.

4）環境省. https://www.env.go.jp/water/impure/haisui.html 